\title{
PENINGKATAN KEMAMPUAN MENULIS KARANGAN SISWA KELAS IV DI MI ATTAHDZIBIYYAH KECAMATAN BABAT KABUPATEN LAMONGAN MELALUI PENGGUNAAN MEDIA GAMBAR BERSERI
}

\author{
FIRDA NUR FAHMI \\ Dosen Program Studi Pendidikan Guru Madrasah Ibtidaiyah \\ Fakultas Agama Islam Universitas Darul 'Ulum Lamongan \\ Email: dahfa_07@yahoo.co.id
}

\begin{abstract}
Penelitian yang berjudul peningkatan kemampuan menulis karangan siswa kelas IV di MI Attahdzibiyah Kecamatan Babat Kabupaten Lamongan melalui penggunaan media gambar berseri ini bertujuan untuk mengetahui apakah penggunaan media gambar berseri dapat meningkatkan kemampuan siswa dalam menyusun cerita menjadi karangan yang utuh sesuai dengan rangkaian gambar yang urut, Bagaimana penerapan media gambar berseri dalam pembelajaran menulis karangan dikelas IV MI Attadzibiyyah Kecamatan Babat Kabupaten Lamongan. Untuk memperoleh hasil penelitian tersebut, peneliti melakukan penelitian tindakan kelas dengan pendekatan kualitatif. Untuk meningkatkan kemampuan siswa dalam menulis karangan, peneliti mengambil tindakan pembelajaran melalui penggunaan media gambar berseri yang dilakukan dengan dua siklus. Model PTK yang digunakan yaitu model Kurt Lewin. Dimana dalam satu siklus terdiri dari empat komponen, meliputi: Perencanaan (planning), tindakan (action), pengamatan (observation), dan refleksi. Adapun teknik pengumpulan data yang digunakan adalah wawancara, observasi, catatan lapangan dan tes. Adapun data yang diperoleh di analisis secara deskriptif dan di analisis dengan menggunakan rumus nilai rata-rata dan persentase ketuntasan belajar. Hasil penelitian menunjukkan bahwa: 1. Penerapan media gambar berseri dalam pembelajaran menulis karangan berjalan dengan baik melalui perbaikan- perbaikan pada tiap siklus. Dalam PBM dapat dilihat dari aktivitas guru dan siswa yang mengalami peningkatan dari siklus I ke siklus II. 2. Tingkat kemampuan siswa dalam menulis karangan pun meningkat dari rata-rata nilai perolehan siswa dari 66,45 pada siklus I yang secara klasikal belum tuntas atau belum memenuhi KKM 70, menjadi 75,625 pada siklus II yang secara klasikal sudah tuntas. Begitu pula dengan ketuntasan belajar yang meningkat dari 33,33\% pada siklus I dengan kategori kurang menjadi 83,33\% pada siklus II dengan kategori tinggi.
\end{abstract}

Kata Kunci: kemampuan menulis karangan, media gambar berseri 


\section{A. PENDAHULUAN}

\section{Latar Belakang Masalah}

Pengajaran penggunaan bahasa Indonesia dilakukan sejak dari sekolah dasar hingga jenjang perguruan tinggi untuk meningkatkan mutu penguasaan bahasa Indonesia. Indikator keberhasilan pengajaran bahasa Indonesia dapat diketahui dari standar kompetensi membaca, menulis, berbicara, dan mendengarkan (menyimak) yang dimiliki oleh peserta didik. Mereka dapat menguasai dan mempraktekkan kompetensi dasar itu dengan baik dan benar.

Menulis merupakan aspek berbahasa yang tidak dapat dipisahkan dari aspek lain dalam proses belajar yang dialami siswa selama menuntut ilmu di sekolah. Dalam kegiatan ini, seorang penulis harus terampil memanfaatkan grafologi, struktur bahasa, dan kosa kata. Dari pernyataan itu, dapat diketahui bahwa menulis merupakan suatu kemampuan berbahasa yang melibatkan berbagai keterampilan. Hal tersebut dapat dikatakan demikian karena penulis memerlukan latihan- latihan yang berkelanjutan dan terus menerus .

Tujuan yang diharapkan dari kegiatan menulis adalah agar siswa mampu mengungkapkan ide atau gagasan, pendapat, dan pengetahuan secara tertulis serta mempunyai hobi menulis. Melalui keterampilan menulis yang dimiliki, siswa dapat mengembangkan kreativitas dan dapat mempergunakan bahasa sebagai sarana komunikasi. Akan tetapi, tidak semua orang mampu melaksanakan tugas menulis dengan baik. Itu bukan pekerjaan yang mudah karena merupakan kemampuan yang kompleks, yang menuntut sejumlah pengetahuan dan keterampilan. Pembelajaran keterampilan menulis pada jenjang sekolah dasar merupakan langkah awal menuju tingkat lanjut ke jenjang pendidikan lebih tinggi. Kemampuan menulis ini diajarkan di MI IV. Kemampuan menulis karangan yang di ajarkan di kelas I dan II merupakan tahap awal, sedangkan yang di ajarkan di kelas III, IV, V, VI disebut tahap lanjut.

Melalui latihan menulis secara bertahap, siswa diharapkan mampu membangun keterampilan menulis lebih meningkat lagi. Akan tetapi, fakta di lapangan menunjukkan bahwa kemampuan menulis siswa masih rendah bila dibandingkan dengan kegiatan berbahasa lainnya. Fenomena rendahnya pembelajaran kemampuan menulis terutama pembelajaran menulis karangan juga terjadi di kelas IV MI Attadzibiyyah Kec. Babat Kabupaten Lamongan. Hal ini dapat dilihat dari data pendukung yang di peroleh pada saat guru memberikan tugas mengarang pada awal semester. 
Berdasarkan hasil interview kepada salah seorang guru di MI Attadzibiyyah Kec. Babat Kabupaten Lamongan diperoleh keterangan bahwa kegiatan pembelajaran menulis yang terjadi di MI Attahdzibiyyah selama ini kurang berjalan dengan lancar dan menemui berbagai hambatan. Secara umum hal ini disebabkan aktivitas menulis merupakan suatu bentuk manifestasi kemampuan dan keterampilan berbahasa yang paling akhir dikuasai setelah kemampuan mendengarkan, berbicara, menyimak dan membaca. Selanjutnya, guru yang bersangkutan bersama peneliti kemudian mengidentifikasi penyebab kegagalan siswa dalam kegiatan menulis.

Dari empat kompetensi dasar itu, masalah mendasar yang dikeluhkan oleh guru kelas IV di MI Attahdzibiyyah Kec. Babat Kabupaten Lamongan pada pembelajaran bahasa Indonesia adalah rendahnya kemampuan menulis siswa, terutama pada pembelajaran menulis karangan. Permasalahan ini ditandai oleh: 1) Rendahnya kemampuan siswa dalam menulis cerita secara kronologis sehingga menjadi karangan yang utuh. 2) Rendahnya kemampuan siswa dalam memadukan hubungan antar kalimat. 3) Rendahnya kemampuan siswa dalam penggunaan ejaan dan tanda baca dalam karangan.

Belajar bahasa Indonesia siswa harus menguasai empat keterampilan berbahasa, yaitu: keterampilan menyimak, berbicara, membaca, dan menulis. Keterampilan menulis merupakan salah satu keterampilan berbahasa yang harus dimiliki oleh para siswa yang sedang belajar mulai tingkat pendidikan dasar (SD) sampai perguruan tinggi (PT). Keterampilan menulis sifatnya fungsional bagi pengembangan diri untuk kehidupan masyarakat.

Membuat kalimat termasuk ke dalam kegiatan untuk keterampilan menulis, karena itu membuat kalimat juga berarti mengungkapkan ide dan berkomunikasi dengan orang lain melalui simbol-simbol bahasa. Dalam membuat kalimat perlu memperhatikan dua hal, yaitu substansi dari hasil tulisan (ide yang diekspresikan) dan aturan struktur bahasa yang benar (grammatical form and syntactic pattern). Unsur-unsur pembentuk kalimat seperti subyek, predikat, obyek dan keterangan dengan benar dan jelas bagi pembaca, mengungkapkan gagasan utama secara jelas, membuat teks koheren, sehingga orang lain mampu mengikuti pengembangan gagasan serta memperkirakan pengetahuan yang dimiliki target pembaca. ${ }^{1}$

Berdasarkan observasi diketahui bahwa faktor penyebab rendahnya kemampuan mengarang siswa adalah diri sendiri dan factor dari guru. Imajinasi adalah salah satu hal

\footnotetext{
${ }^{1}$ Nanik Setyawati, Analisis kesalahan berbahasa Indonesia.2010
} 
yang menyebabkan sulitnya siswa dalam menuangkan ide ke dalam bentuk karangan, siswa belum mampu merangkai kata- kata menjadi satu kalimat dan menyusunnya menjadi karangan yang utuh, selain itu pemahaman siswa terhadap ejaan dan tanda baca dalam kegiatan mengarang sangatlah kurang. Sedangkan faktor rendahnya kemampuan mengarang siswa dari faktor guru adalah kurangnya kreatifitas guru dalam menggunakan alat (media).

Bertitik tolak dari masalah tersebut, peneliti ini di fokuskan pada pembelajaran menulis karangan. Pemilihan pembelajaran menulis karangan di dasarkan pada masalah yang timbul pada masalah proses pembelajaran mengarang serta didasarkan pada masalah yang timbul dalam proses pembelajaran mengarang dan didasarkan pada kompetensi dasar pada pembelajaran menulis kelas IV pada semester II yaitu menulis karangan sesuai dengan ejaan (huruf besar, tanda titik dan koma), indikator yang dapat dicapai siswa adalah: 1) Siswa dapat menulis sesuai dengan memperhatikan ejaan ( huruf besar, tanda titik dan koma). 2) Siswa dapat membuat kalimat sesuai dengan maksud dan menyusunnya sesuai dengan ejaan. 3) Dapat menyusun rangkaian kalimat menjadi kalimat yang padu sehingga menjadi suatu karangan yang utuh.

Pada hakikatnya menulis adalah pengutaraan sesuatu dengan menggunakan bahasa secara tertulis. Dengan mengutarakan sesuatu itu dimaksudkan, menyampaikan, memberitakan, melukiskan, menerangkan, meyakinkan, menjelmakan, dan sebagainya kepada pembaca agar mereka memahami apa yang terjadi pada suatu peristiwa atau kegiatan. Di dalam menulis terdapat empat unsur yaitu: 1) Menulis merupakan bentuk ekspresi diri. 2) Menulis merupakan sesuatu yang umum disampaikan ke pembaca. 3) Menulis merupakan aturan dan tingkah laku. 4) Menulis merupakan sebuah cara belajar.

Sehubungan dengan hal tersebut, kegiatan pembelajaran Bahasa Indonesia khususnya keterampilan menulis karangan kurang bergairah sehingga siswa tidak terampil menggunakan kemampuannya dalam mengikuti pembelajaran menulis. Hal itu perlu diadakan Penelitian Tindakan Kelas (PTK).

Menulis merupakan keseluruhan rangkaian kegiatan siswa dalam mengungkapkan buah pikirannya melalui bahasa tulis untuk dibaca dan dimengerti oleh guru atau siswa lainnya. Buah pikiran itu dapat berupa pengalaman, pendapat, pengetahuan, keinginan, perasaan sampai gejolak kalbu siswa itu sendiri. Buah pikiran itu diungkapkan dan disampaikan kepada pihak lain dengan wahana berupa bahasa tulis, yakni bahasa yang 
tidak mempergunakan peralatan bunyi dan pendengaran melainkan berwujud berbagai tanda dan lambang yang harus dibaca.

Kemampuan menulis tidak datang begitu saja, perlu adanya pengetahuan yang harus dikuasai dan dipahami siswa. Menulis memerlukan trik-trik atau kiat-kiat sehingga hasil tulisan sesuai dengan hasil tulisan yang dipersyaratkan. Untuk mencapai hasil tulisan yang maksimal perlu adanya proses pembelajaran yang menyenangkan. Dari pembelajaran menulis pada kelas IV semester II adalah menulis karangan berdasarkan tentang berbagai topik sederhana dengan memperhatikan ejaan (huruf besar, tanda titik dan tanda koma). ${ }^{2}$ Maka diperlukan media yang berupa gambar seri yang dapat memudahkan kemampuan siswa dalam menulis karangan. Dengan demikian mengacu kepada penjabaran di atas, dapat dikemukakan bahwa diduga pembelajaran dengan menggunakan media gambar ini dapat meningkatkan kemampuan menulis siswa.. Berbekal dari permasalahan yang terjadi diatas maka penulis menggunakan media gambar berseri yang akan menarik anak untuk mengoptimalkan kemampuannya

\section{Rumusan Masalah}

Sesuai dengan latar belakang masalah yang dijelaskan diatas, maka dapat dirumuskan masalah sebagai berikut:

1. Apakah penggunaan media gambar berseri dapat meningkatkan kemampuan siswa dalam menyusun cerita menjadi karangan yang utuh sesuai dengan rangkaian gambar yang urut?

2. Bagaimana penerapan media gambar berseri dalam pembelajaran menulis karangan dikelas IV MI Attahdzibiyyah?

\section{Tujuan Penelitian}

1. Untuk mengetahui kemampuan siswa dalam menyusun cerita sehingga menjadi karangan yang utuh sesuai dengan rangkaian gambar yang urut.

2. Untuk mengetahui penerapan pembelajaran menulis karangan dengan media gambar berseri dikelas IV MI Attahdzibiyyah di kecamatan Babat kabupaten Lamongan.

\footnotetext{
${ }^{2}$ Hanif Nurcholis, Saya senang berbahasa Indonesia untuk kelas IV. Erlangga
} 


\section{B. PEMBAHASAN}

\section{Kemampuan Menulis Karangan}

Kemampuan dapat dipahami sebagai interaksi yang mengubah energi menjadi pancaran yang dahsyat. Dalam konteks belajar kemampuan dapat dimaknai sebagai interaksi yang terjadi dalam proses belajar niscaya mampu mengubah berbagai potensi yang ada didalam diri manusia menjadi pancaran atau ledakan- ledakan gairah (dalam memperoleh hal- hal baru) yang dapat ditularkan atau ditunjukkan kepada orang lain. ${ }^{3}$

Kemampuan berkomunikasi bisa juga disebut kemampuan berbahasa karena didalam kemampuan berkomunikasi kita menggunakan bahasa sebagai media utamanya. Oleh karena itu kemampuan berkomunikasi dapat dijabarkan sesuai dengan tingkat- tingkat kemampuan bahasa yaitu: 1) Kemampuan menyimak, 2) Kemampuan berbicara, 3) Kemampuan menulis, 4) Kemampuan membaca. ${ }^{4}$

Keterampilan mengarang dan menulis sangat penting untuk mengekspresikan diri. Karangan atau tulisan baik menguntungkan pengarang atau penulis. Sebaliknya, karangan atau tulisan buruk dapat merugikan pengarang atau penulis. ${ }^{5}$

Kemampuan menulis adalah menyampaikan ide atau gagasan dan pesan dengan menggunakan lambang grafik atau tulisan. Menulis merupakan suatu kegiatan untuk menciptakan suatu catatan atau informasi pada suatu media dengan menggunakan aksara. Menulis biasa dilakukan pada kertas dengan menggunakan alat- alat seperti pena atau pensil. Pada awal sejarahnya menulis dilakukan dengan menggunakan gambar, contohnya tulisan hieroglif ( hieroglyph) pada zaman mesir kuno. Tulisan dengan aksara muncul sekitar 5000 tahun lalu, orang-orang Sumeria (Irak saat ini) menciptakan tanda-tanda pada tanah liat. Tanda-tanda tersebut mewakili bunyi, berbeda dengan huruf-huruf hieroglif yang mewakili kata- kata atau benda.

Kegiatan menulis berkembang pesat sejak diciptakannya teknik percetakan yang menyebabkan orang makin giat menulis karena karya mereka mudah diterbitkan. Keterampilan menulis merupakan salah satu mata kuliah yang diajarkan di perguruan tinggi. Dalam karangan, kadang-kadang ditemukan kesalahan- kesalahan struktur kalimat, kesalahan bentukan kata, kesalahan penulisan kata, kesalahan penggunaan ejaan, dan kesalahan koherensi paragraph. Untuk mengantisipasi kesalahan ini setiap karangan siswa

\footnotetext{
${ }^{3}$ Hernowo, Quantum Writing, (Bandung:MLC, 2006) Jilid 5, 10

${ }^{4}$ Kaswan Darmadi, Meningkatkan Kemampuan Menulis, (Yogyakarta: Andi Offset, 1996) Jilid 1, 1

${ }^{5}$ Arief Suadi, Mengarang dan Menulis, (Yogyakarta: BPFE Yogyakarta, 2007) jilid 1, 2
} 
diperiksa, kesalahan ditunjukkan, kemudian diperbaiki. Karangan belajar biasanya dibacakan didalam kelas oleh pebelajar yang bersangkutan, disimak oleh pebelajar lain, kemudian dijadikan bahan diskusi diantara mereka untuk memperoleh inspirasi topic karangan dan pengembangannya. Manfaat dari kegiatan menulis diantaranya adalah sebagai berikut: 1) Dengan menulis kita dapat lebih mengenali kemampuan dan potensi diri kita, 2) Melalui kegiatan menulis kita mengembangkan berbagai gagasan, 3) Kegiatan menulis memaksa kita lebih banyak menyerap, mencari, serta menguasai informasi sehubungan dengan topic yang kita tulis, 4) Menulis berarti mengorganisir gagasan secara sistematis serta mengungkapkannya secara tersurat, 5) Melalui tulisan kita akan dapat meninjau serta menilai gagasan kita sendiri secara lebih obyektif, 6) Dengan menuliskan diatas kertas kita akan lebih mudah memecahkan masalah, yaitu dengan menganalisisnya secara tersurat dalam konteks yang lebih konkret, 7) Tugas menulis mengenai suatu topik mendorong kita belajar secara aktif, 8) Kegiatan menulis yang terencana akan membiasakan kita berfikir serta berbahasa secara tertib. ${ }^{6}$

Mengarang berarti menyusun atau merangkai. Secara luas mengarang dapat diartikan sebagai pekerjaan merangkai kata, kalimat dan alinea untuk menjabarkan atau mengulas topic dan tema tertentu guna memperoleh hasil akhir berupa karangan. Menurut pendapat Widyamata dan Sudiati mengarang adalah keseluruhan rangkaian kegiatan seseorang untuk mengungkapkan gagasan dan menyampaikannya melalui bahasa tulis kepada para pembaca untuk dipahami.

Sedangkan pengertian karangan adalah karangan merupakan hasil penjabaran suatu gagasan secara resmi dan teratur tentang suatu topic atau pokok bahasan. Setiap karangan yang ideal pada prinsipnya merupakan uraian yang lebih tinggi atau lebih luas dari alinea.

Dalam proses karang mengarang setiap ide perlu dilibatkan pada suatu kata, katakata dirangkai menjadi sebuah kalimat membentuk paragaf, dan paragraf-paragraf akhirnya mewujudkan sebuah karangan, sedangkan karangan merupakan hasil dari kegiatan mengarang, yaitu perwujudan gagasan seseorang dalam bahasa tulis yang dapat dibaca dan di pahami oleh orang lain.

Dari uraian tersebut diatas dapat disimpulkan bahwa mengarang adalah kegiatan menulis yang tersusun dengan teratur dari kata, kalimat, sampai paragraf yang saling berhubungan dan merupakan kesatuan yang utuh, dengan maksud menceritakan kejadiaan atau peristiwa, mempercakapkan sesuatu, dan tujuan lainya.

\footnotetext{
${ }^{6}$ Sabarti Akhadiah, Pembinaan Kemampuan Menulis Bahasa Indonesia, (Jakarta: Erlangga, 1996) Jilid 10, 1
} 


\section{Media pembelajaran}

\section{a. Pengertian Media Pembelajaran}

Secara harafiah media berarti perantara atau pengantar. Media pembelajaran adalah sarana untuk meningkatkan kegiatan proses belajar mengajar. Sadiman mengemukakan bahwa media adalah perantara atau pengantar pesan dari pengirim ke penerima pesan. Gagne menyatakan bahwa media adalah berbagai jenis komponen dan lingkungannya. Dijelasakn pula pleh raharjo bahwa media adalah wadah dari pesan yang oleh sumbernya ingin diteruskan kepada sasaran atau penerima pesan tersebut. Materi yang diterima adalah pesan intruksional, sedangkan tujuan yang dicapai adalah tercapainya proses belajar. $^{7}$

Gerlach dan Ely mengatakan bahwa media apabila dipahami secara garis besar adalah manusia, materi atau kejadian yang membangun kondisi yang membuat siswa mampu memperoleh pengetahuan, keterampilan atau sikap. Dalam pengertian ini guru, buku teks, dan lingkungan sekolah merupakan media. Secara lebih khusus pengertian media dalam proses belajar mengajar cenderung diartikan sebagai alat-alat grafis, photografis atau elektronisuntuk menangkap. Memproses dan menyusun kembali informasi visual atau verbal. $^{8}$

\section{b. Fungsi Dan Peranan Media Pembelajaran}

Levie dan lentz mengemukakan empat fungsi media pembelajaran, khususnya media visual yaitu:

1) Fungsi atensi media visual merupakan inti, yaitu menarik dan mengarahkan perhatian siswa untuk berkonsentrasi kepada isi pelajaran yang berkaitan dengan makna visual yang ditampilkan atau menyertai teks materi pelajaran. Seringkali pada awal pelajaran siswa tidak tertarik dengan materi pelajaran atau materi pelajaran itu merupakan salah satu pelajaran yang tidak disenangi oleh mereka sehingga mereka tidak memperhatikan.

2) Fungsi afektif media visual dapat terlihat dari tingkat kenikmatan siswa ketika belajar (atau membaca) teks yang bergambar. Gambar atau lambing visual dapat menggungah emosi dan sikap siswa, misalnya informasi yang menyangkut masalah sosial atau ras.

\footnotetext{
${ }^{7}$ Cecep Kustandi. dan Bambang Sutjipto, Media Pembelajaran Manual Dan Digital. (Bogor: Ghalia Indonesia, 2011) Jilid 1,7

${ }^{8}$ Azhar Arsyad, Media Pembelajaran, ( Jakarta: PT Raja Grafindo Persada, 2008) Jilid 1, 3
} 
3) Fungsi kignitif media visual terlihat dari temuan- temuan penelitian yang mengungkapkan bahwa lambing visual atau gambar memperlancar pencapaian tujuan untuk memahami dan menginat informasi atau pesan yang terkandung dalam gambar.

4) Fungsi kompensatoris media pembelajaran terlihat dari hasil penelitian bahwa media visual yang memberikan konteks untuk memahami teks membantu siswa yang lemah dalam membaca untuk mengorganisasikan informasi dalam teks dan mengingatnya kembali. Dengan kata lain, media pembelajaran berfungsi untuk mengakomodasi siswa yang lemah dan lambat menerima serta memahami isi pelajaran yang di sajikan dengan teks atau disajikan secara verbal. ${ }^{9}$

Ketika fungsi-fungsi media pembelajaran itu diaplikasikan maka terlihatlah peranannya sebagai berikut:

1) Media pembelajaran dapat memperjelas penyajian pesan dan informasi sehingga dapat memperlancar serta meningkatkan proses dan hasil belajar.

2) Media pembelajaran dapat meningkatkan dan mengarahkan perhatian anak, sehingga dapat menimbulkan motivasi belajar, interaksi yang lebih langsung antara siswa dan lingkungannya.

3) Media pembelajaran dapat mengatasi keterbatasan indera, ruang dan waktu.

4) Media pembelajaran dapat memberikan kesamaan pengalaman kepada siswa tentang peristiwa- peristiwa dilingkungan mereka, serta memungkinkannya terjadinya interaksi langsung dengan guru, masyarakat dan lingkungannya.

\section{c. Kriteria Pemilihan Media Pembelajaran}

Kriteria pemilihan media bersumber dari konsep bahwa media merupakan bagian dari system instruksional secara keseluruhan. Untuk itu ada beberapa kriteria yang patut dperhatikan dalam memilih media.

\section{1) Sesuai dengan tujuan yang ingin dicapai.}

Media dipilih berdasarkan tujuan pembelajaran yang telah ditetapkan dan secara umum, mengacu kepada salah satu atau gabungan dari dua atau tiga ranah kognitif.

\footnotetext{
${ }^{9}$ Cecep Kustandi. dan Bambang Sutjipto, Media Pembelajaran Manual Dan Digital. (Bogor: Ghalia Indonesia, 2011) Jilid 1. 22
} 
2) Tepat untuk mendukung isi pelajaran yang sifatnya fakta, konsep, prinsip atau generalisasi.

Media yang berbeda, misalnya film dan grafik, memerlukan symbol dank ode yang berbeda, karenanya memerlukan proses dan keterampilan mental yang berbeda untuk memahaminya.

\section{3) Praktis, luwes dan bertahan.}

Jika tidak tersedia waktu, dana atau sumber daya lainnya untuk memproduksi, tidak perlu dipaksakan. Media yang mahal dan memakan waktu lama untuk memprokdusinya. kriteria ini menuntun para guru untuk memilih media yang ada, mudah diperoleh, atau mudah dibuat sendiri oleh guru.

\section{4) Guru terampil menggunakannya.}

Ini merupakan salah satu kriteria utama. Apa pun media itu, guru harus mampu menggunakannya dalam proses pembelajaran. Nilai dan manfaat amat ditentukan oleh guru yang menggunakannya.

\section{5) Pengelompokan sasaran.}

Media yang efektif untuk kelompok besar belum tentu sama efektifnya jika digunakan dalam kelompok kecil atau perorangan. Ada media yang tepat untuk jenis kelompok besar, kelompok sedang, kelompok kecil dan seterusnya.

\section{6) Mutu teknis.}

Pengembangan visual baik gambar maupun fotografi harus memenuhi persyaratan teknis tertentu.

Selain beberapa hal diatas, sebelum memutuskan untuk memanfaatkan media dalam kegiatan pembelajaran didalam kelas, hendaknya kita melakukan seleksi terhadap media pembelajaran mana yang akan digunakan untuk mendampingi kita dalam membelajarkan peserta didik. Berikut ini disajikan beberapa tips atau pertimbangan- pertimbangan yang dapat digunakan guru dalam melakukan seleksi terhadap media pembelajaran yang akan digunakan diantaranya sebagai berikut:

\section{1) Sesuaikan jenis media dengan materi kurikulum.}

Sewaktu akan memilih media yang akan dikembangkan atau diadakan, maka yang perlu diperhatikan adalah jenis materi yang mana terdapat didalam kurikulum yang di nilai perlu di tunjang oleh media pembelajaran, kemudian dilakukan telaah tentang jenis media apa yang dinilai tepat untuk menyajikan materi pelajaran yang dikehendaki 
tersebut. Salah satu prinsip umum pemilihan atau pemanfaatan media adalah tidak ada satu jenis media yang cocok atau tepat untuk menyajikan semua materi pelajaran.

\section{2) Keterjangkauan dalam pembiayaan.}

Dalam pengembangan atau pengadaan media pembelajaran hendaknya juga mempertimbangkan ketersediaan anggaran yang ada.

\section{3) Ketersediaan perangkat keras untuk pemanfaatan media pembelajaran.}

Pemilihan media sederhana ( seperti media kaset audio ) untuk dirancang dan dikembangakan akan sangat bermanfaat karena peralatan atau fasilitas pemanfaatannya tersedia di sekolah atau mudah diperoleh masyarakat.

\section{4) Ketersediaan media pembelajaran di pasaran.}

Guru harus lebih pintar memilih media yang di belinya di pasaran itu apakah sesuai dengan materi pelajarannya atau tidak. Dapat saja terjadi, media pembelajaran yang telah dipesan dan dipelajari, kandungan materinnya sedikit sekali yang relevan dengan kebutuhan peserta didik ( sangat dangkal ). Sebaliknya dapat juga terjadi bahwa materi yang dikemas didalam pembelajaran sangat cocok dan membantu siswa memahami materi pelajaran. Namun, yang menjadi masalah adalah bahwa media pembelajaran tersebut sulit di dapatka di pasaran.

\section{5) Kemudahan memanfaatkan media pembelajaran.}

Aspek lain yang juga tidak kalah pentingnya untuk dipertimbangkan dalam pengembangan atau pengadaan media pembelajaran adalah kemudahan guru atau peserta didik dalam memanfaatkannya. Tidak akan terlalu bermanfaat apabila media pembelajaran yang dikembangkan sendiri atau yang dikontrakkan oleh pembuatnya, ternyata tidak mudah dimanfaatkan, baik oleh guru maupun peserta didik. Media yang dikembangkan atau dibeli tersebut hanya berfungsi sebagai pajangan disekolah, sehingga dibutuhkan waktu yang memadai untuk melatih guru tertentu agar dapat terampil mengoprasikan peralatan tersebut. ${ }^{10}$

\section{Media Cerita Gambar Berseri Sebagai Media Pembelajaran}

Media gambar adalah media pembelajaran yang sering digunakan. Media ini merupakan bahasa yang umum, dapat dimengerti, dan dinikmati oleh semua orang dimana- mana. Gambar berfungsi untuk menyampaikan pesan melalui gambar yang menyangkut indera penglihatan. Pesan yang disampaikan dituangkan ke dalam symbol-

\footnotetext{
${ }^{10}$ Cecep Kustandi. dan Bambang Sutjipto, 91
} 
symbol komunikasi visual. Symbol-simbol tersebut perlu dipahami benar agar proses penyampaian pesan dapat berhasil dan efisien. Selain itu media grafis mempunyai tujuan untuk menarik perhatian, memperjelas materi, mengilustrasikan fakta atau informasi yang mungkin akan cepat jika di ilustrasikan dengn gambar. ${ }^{11}$

Dalam kriteria pemilihan media disinggung bahwa media digunakan harus sesuai dengan taraf berfikir anak didik. Demekian pula dengan pembelajaran menulis karangan di tingkat SD atau MI. penggunaan media gambar berseri dirasakan sangat tepat untuk membantu siswa dalam keterampilan mengarang. Dengan melihat gambar siswa dapat menarik kesimpulan dari gambar tersebut, kemudian dapat menguraikan dalam bentuk tulisan.

Gambar berseri merupakan salah satu bentuk media gambar yang memiliki urutan waktu tertentu yang menggambarkan suatu peristiwa atau kejadian dan dapat pula berbentuk suatu cerita tersusun. Media gambar seri sangat cocok digunakan untuk membentuk pikiran yang teratur.

Gambar yang baik dan dapat digunakan sebagai sumber belajar adalah yang memiliki ciri-ciri sebagai berikut: 1) Dapat menyampaikan pesan atau ide tertentu., 2) Memberi kesan kuat dan menarik perhatian 3) Merangsang orang yang melihat untuk ingin mengungkapkan tentang obyek-obyek dalam gambar, 4) Berani dan dinamis, 4) Ilustrasi tidak terlalu banyak, tetapi menarik dan mudah dipahami.

Sedangkan peranan gambar sebagai media pengajaran yaitu: 1) Dapat membantu guru dalam menyampaikan pelajaran dan membantu siswa dalam belajar, 2) Menarik perhatian siswa sehingga terdorong untuk lebih giat belajar, 3) Dapat membantu daya ingat siswa, 4) Dapat disimpulkan dan digunakan lagi apabila diperlukan pada saat yang lain.

Atas dasar uraian tersebut diatas, hendaknya guru mau mempertimbangkan penggunaan media gambar seri didalam pelaksanaan proses belajar mengajar terutama dalam pengajaran menulis karangan. Karena dengan gambar dapat merangsang imajinasi seorang siswa supaya suka bercerita tentang gambar yang dilihatnya sehingga selanjutnya diharapkan siswa tersebut dapat mampu menulis karangan sesuai dengan tema, ide, pengalaman dan kejadianya.

Dari uraian diatas dapat ditarik kesimpulan bahwa cerita gambar berseri adalah cara atau upaya dalam menyusun atau menulis suatu tulisan atau karangan dengan menerjemahkan isi pesan visual (gambar berseri) kedalam bentuk tulisan.

${ }^{11}$ Cecep Kustandi. danBambang Sutjipto, Jilid 1, 45 


\section{HASIL PENELITIAN DAN PEMBAHASAN}

1. Siklus I

Siklus pertama terdiri dari empat tahap, yakni perencanaan, pelaksanaan, observasi dan refleksi, seperti berikut:

a. Tahap perencanaan

Pada tahap perencanaan siklus I ini kegiatan yang dilakukan adalah: 1) Membuat rencana pembelajaran dengan menggunakan media gambar berseri, 2) Membuat jadwal kunjungan kelas, 3) Membuat instrumen pembelajaran (RPP, lembar materi ahli, rangkaian media gambar berseri, lembar observasi), 4) Mencari guru yang akan dijadikan kolaborasi, yang faham tentang mata pelajaran yang akan menjadi sumber PTK.

b. Pelaksanaan Tindakan

Pelaksanaan tindakan siklus I ini dilaksanakan pada tanggal 30 April 2017 di kelas IV dengan jumlah siswa 24 siswa dan semuanya adalah siswa laki-laki. Pada saat awal siklus pertama ini, siswa belum terbiasa dengan pembelajaran menulis karangan dengan menggunakan media gambar berseri. Namun untuk mengatasi masalah pada siklus pertama ini, guru mengarahkan siswa untuk mendeskripsikan cara menulis karangan sesuai dengan tanda baca (titik, koma), ejaan huruf besar, perpaduan antar paragraph satu dengan paragraph lain dan perpaduan antar kalimat satu dengan kalimat lain dengan menggunakan media gambar berseri. Hal ini terlihat dari siswa mampu menyusun sebuah karangan dengan tema jajan sembarangan sesuai dengan ejaan huruf besar, perpaduan antar paragraph satu dengan paragraph lain dan perpaduan antar kalimat satu dengan kalimat.

c. Tahap pengamatan atau observasi

Dengan menggunakan hasil pengamatan guru: bahwa guru sudah memberikan pembelajaran yang cukup baik kepada siswa. Tetapi metode yang digunakan masih baru maka masih ada sedikit kendala yang harus diperbaiki oleh guru agar menampakkan kinerja menjadi lebih baik. Hasil pengamatan siswa bahwa respon siswa dalam keikutsertaan terhadap pembelajaran sudah cukup baik, akan tetapi dengan metode yang baru tersebut dibutuhkan waktu agar siswa terbiasa sehingga dapat mengikuti pelajaran dengan maksimal. Dapat di simpulkan bahwa guru harus bisa memberikan motivasi yang lebih dan menjadikan pelajaran tersebut sebagai pelajaran yang menyenangkan agar siswa bisa lebih aktif. dan hasil tes belajar dengan menggunakan pembelajaran 
media gambar berseri diperoleh nilai rata-rata belajar siswa adalah 66,45 dan ketuntasan belajar mencapai 33,33\% atau ada 8 siswa dari 24 siswa sudah tuntas belajar. Hasil tersebut menunjukkan bahwa pada siklus I secara klasikal siswa belum tuntas belajar, karena siswa yang memperoleh nilai kurang dari 70 hanya sebesar $33.33 \%$ lebih kecil dari presentase yang dikehendaki yaitu sebesar $85 \%$. Tingkat ketuntasan belajar siswa masih rendah, sehingga perlu dilaksanakan siklus II untuk meningkatkan ketuntasan belajar.

d. Tahap refleksi

Adapun hasil refleksi pada siklus I adalah sebagai berikut:

1) Secara klasikal hasil belajar yang diperoleh siswa belum mencapai ketuntasan dikarenakan siswa merasa baru dengan penggunaan media gambar berseri.

2) Untuk memperbaiki pembelajaran siklus I ini, guru akan lebih mengarahkan siswa dalam menulis karangan sesuai dengan ejaan, pilihan kata, perpaduan antar paragraph satu dengan paragraph lain dan penggunaan antar kalimat satu dengan kalimat lain.

2. Siklus II

a. Tahap perencanaan

Pada tahap ini peneliti membuat rencana pembelajaran berdasarkan hasil refleksi pada siklus I

b. Pelaksanaan Tindakan

Pelaksanaan kegiatan belajar mengajar untuk siklus II dilaksanakan pada tanggal 11 Mei 2017 dengan jumlah siswa 24 siswa laki-laki. Pada siklus kedua ini siswa sudah terbiasa dengan penggunaan media gambar berseri dan siswa mulai termotivasi kembali untuk menulis karangan. Dalam proses pembelajaran dengan menggunakan media gambar berseri ini siswa bisa menentukan sendiri tema pada gambar tersebut dan tema pada siklus kedua ini menggunakan tema anjing dan kancil, selain itu juga mereka sudah mengerti bagaimana cara menulis karangan yang baik, tentunya dengan menggunakan tanda baca (titik, koma), ejaan huruf besar, perpaduan antar paragraph satu dengan paragraph lain dan perpaduan antar kalimat satu dengan kalimat lain dan bisa menghasilkan karya yang baik.

c. Tahap Pengamatan

Hasil pengamatan guru: menunjukkan bahwa peningkatan pada siklus II sangat baik, karena guru lebih bisa menghidupkan suasana dalam kelas ketika pelajaran berlangsung 
dengan berbagai penjelasan dan interaksi terhadap siswa. Hasil pengamatan siswa: bahwa siswa lebih aktif dan bersemangat dalam pembelajaran karena suasana dalam kelas lebih hidup, sehingga tidak menjadikan kejenuhan dan siswa lebih memahami pembelajaran dengan maksimal. Hasil tes belajar: Dari data hasil tes di peroleh nilai rata-rata belajar siswa 75,625 dan ketuntasan belajar mencapai $83,33 \%$ atau ada 20 siswa dari 24 siswa sudah tuntas belajar. Hasil ini menunjukkan bahwa pada siklus II ketuntasan belajar siswa secara klasikal telah mengalami peningkatan sedikit lebih baik daripada siklus I.

d. Tahap Refleksi

Adanya peningkatan hasil belajar pada siklus II dikarenakan respon siswa terhadap pembelajaran tersebut lebih baik daripada siklus I. maka tidak perlu revisi terlalu banyak, tetapi yang perlu diperhatikan untuk tindakan selanjutnya adalah memaksimalkan dan mempertahankan hal yang telah ada dengan tujuan agar pelaksanaan pembelajaran selanjutnya dapat tercapai dengan baik.

Dari hasil kegiatan pembelajaran menulis karangan dengan menggunakan media pembelajaran gambar berseri yang telah dilakukan selama dua siklus, diperoleh beberapa temuan hasil tindakan sebagai berikut:

1. Hasil yang diperoleh menunjukkan penerapan pembelajaran menulis karangan melalui penggunaan media gambar berseri berjalan dengan baik melalui perbaikan- perbaikan pada tiap siklus. Pada siklus pertama, penerapan pembelajaran memberikan motivasi yang baik. Dalam proses pembelajaran menggunakan media gambar berseri dengan tema jangan jajan sembarangan siswa dapat menuangkan ide mereka kedalam bentuk tulisan, selain itu juga mereka bisa mendeskripsikan cara menulis karangan sesuai dengan tanda baca (titik, koma), ejaan huruf besar, perpaduan antar paragraph satu dengan paragraph lain dan perpaduan antar kalimat satu dengan kalimat lain. Pada siklus kedua, siswa mulai termotivasi kembali untuk menulis karangan. Dalam proses pembelajaran dengan menggunakan media gambar berseri ini siswa bisa menentukan sendiri tema pada gambar tersebut, selain itu juga mereka sudah mengerti bagaimana cara menulis karangan yang baik, tentunya dengan menggunakan tanda baca (titik, koma), ejaan huruf besar, perpaduan antar paragraph satu dengan paragraph lain dan perpaduan antar kalimat satu dengan kalimat lain agar bisa menghasilkan karya yang baik. 
2. Berdasarkan analisis data, diperoleh bahwa:

a) Dalam proses belajar mengajar dapat dilihat dari aktifitas guru dan siswa mengalami peningkatan dari siklus I ke siklus II.

b) Dengan meningkatnya proses belajar mengajar diatas menyebutkan tingkat kemampuan menulis karangan siswa pun meningkat. Hal ini dapat dilihat dari rata-rata nilai perolehan siswa pada tes hasil belajar dari 66,45 pada siklus I yang secara klasikal belum tuntas atau belum memenuhi KKM 70. 75,625 pada siklus II. Begitu pula dengan ketuntasan belajar yang meningkat dari 33,33\% pada siklus I dengan kategori kurang, menjadi 83,33\% pada siklus II dengan kategori tinggi.

Dengan demikian, pembelajaran melalui penggunaan media gambar berseri ini dapat memberikan pengalaman siswa untuk menulis karangan dengan menyenangkan dan hal tersebut telah menumbuhkan kreatifitas yang tinggi.

\section{KESIMPULAN}

Kegiatan perbaikan pembelajaran yang telah dilaksanakan selama 2 siklus ini dapat meningkatkan kemampuan siswa dalam menulis karangan mata pelajaran Bahasa Indonesia dan berdasarkan seluruh pembahasan serta analisis dan observasi yang telah dilakukan oleh guru dan peneliti, dapat disimpulkan sebagai berikut:

1. Pembelajaran dengan menggunakan metode pembelajaran mengarang dengan menggunakan media gambar berseri pada mata pelajaran bahasa Indonesia kelas IV MI Attahdzibiyyah Kec. Babat Kabupaten memiliki dampak positif dalam meningkatkan kemampuan belajar siswa. Pemahaman siswa terhadap materi melalui metode pembelajaran benar-benar mempunyai makna bagi siswa karena siswa lebih aktif belajar dan lebih mudah memahami pelajaran.

2. Penerapan media pembelajaran dapat meningkatkan pemahaman belajar siswa kelas IV MI Attadzibiyyah Kecamatan Babat Kabupaten Lamongan, hal ini terbukti dari hasil penilaian saat pembelajaran dengan menggunakan media pembelajaran mengalami peningkatan. Rata-rata Kelas mengalami peningkatan dari siklus I yang hanya 66,45, pada siklus II mencapai 72,625. Ketuntasan belajar siswa juga meningkat dari $33,33 \%$ pada siklus I menjadi $83,33 \%$ pada siklus II. 


\section{E. DAFTAR PUSTAKA}

Akhadiah, Sabarti, Pembinaan Kemampuan Menulis Bahasa Indonesia, Jakarta: Erlangga, 1996

Arsyad, Azhar, Media Pembelajaran, Jakarta: PT Raja Grafindo Persada, 2008

Darmadi, Kaswan, Meningkatkan Kemampuan Menulis, Yogyakarta: Andi Offset, 1996

Hernowo, Quantum Writing, Bandung: MLC, 2006

Kustandi. Cecep dan Bambang Sutjipto, Media Pembelajaran Manual Dan Digital. Bogor: Ghalia Indonesia, 2011

Nurcholis, Hanif, Saya senang berbahasa Indonesia untuk kelas IV. Erlangga

Setyawati, Nanik, Analisis kesalahan berbahasa Indonesia.2010

Suadi, Arief Mengarang dan Menulis, Yogyakarta: BPFE Yogyakarta, 2007. 